\title{
Seasonal Variation of Solid Waste Components in Ranya District, Iraq.
}

\section{Araz Ahmed Hamza}

Department of Civil Engineering, Presidency of University of Raparin, University of Raparin-Rania, Kurdistan Region - Iraq.

E-mail: Araz.hamza@uor.edu.krd

\section{Omed Aziz Ahmed}

Mechanical Engineer, Supervisor Engineer of Solid Waste Management in Ranya, Municipality of Rania, Rania, Kurdistan Region - Iraq.

E-mail: Omed_hemn@yahoo.com

\begin{abstract}
:
Municipal solid waste can be considered as one of the significant environmental issues in worldwide, as a result of industrial revolution, economic development and overpopulation. The current study focused on seasonal variation of solid waste production and composition. The study was conducted during winter and summer seasons in 2019. Solid waste samples were collected from the collector trucks from eight different zones in Ranya district. The results revealed that the average of total solid waste generation in the district estimated as (286.9 tons/day) and (1.108 kg-capita/days). The analysis of the waste content detected that the largest portion of the district solid waste is organic material which forming an average of $67.05 \%$. Followed by cloth \& textile, plastic, paper \& cardboards, metal and glass, which their quantities are $11.93 \%, 8.19 \%, 7.12 \%, 3.05 \%$ and $2.65 \%$ respectively. The seasonal variation impacts on solid waste has been preserved obviously in this research study, more specifically in metal, glass and organic waste contents, which their quantities increased substantially from wet to dry season, (6.2 to 11.61 tons/day), (6.26 to 9.07 tons/day) and (177.5 to 207.62 tons/day) respectively. Moreover, the total generated solid waste magnitude of the district picked up changed from 268.37tones/day for wet season to 305.44tones/day for dry season.
\end{abstract}

Key Words:Municipal solid waste, Ranya District, Solid Waste management. 


\section{INTRODUCTION:}

Solid waste management is a universal phenomenon; the major reasons behind of producing a tremendous quantity of waste are urbanization, industrialization and overpopulation. Recently, researches indicated that the Asian municipal solid waste generation is about 760,000 tons per day, which is equivalent to about 2.7 million $\mathrm{m}^{3} / \mathrm{day}$. And it has been expected to increase to 1.8 million tons/day and $5.2 \mathrm{~m}^{3} /$ day in 2025 (Daniel H. et al, 1999).

Household solid waste can be defined as any refused or unwanted solid material generated as a result of daily domestic routines or human activates. And it is complicated to manage since it be composed of miscellaneous aggregate of materials such as (foods, organic matter, glass, metals, plastics, papers, nylon, vegetable, dead animals etc.). Most commonly, they are in the state of solids, semi solids or liquids in containers thrown out of households, commercial or industrial zones. (Adefemi and Awokunmi, 2009).

Overpopulation, urbanization, financial statue, industrialization, the lifestyle (culture and traditions) of the inhabitants and the seasons are significantly associated with both the quantity of solid waste generated per capita (quantity of wastes generated / total population) called waste generation rate expressed in $\mathrm{kg} / \mathrm{capita} / \mathrm{day}$, and the solid waste ingredients. The quantity and configuration of waste produced differs by country, region or even in different areas of a city. Thus, the average of waste generation is between $(0.80-2.2 \mathrm{~kg} / \mathrm{capita} /$ day $)$ in countries with middle and high income, while to low-income countries it is between $0.3-0.9 \mathrm{~kg} / \mathrm{capita} /$ day (Daniel Hoornweg, P. Bhada-Tata, 2012). Solid waste has a direct impact on health of people who live in the neighboring, Leachate from landfill and solid waste dump sites are the major sources of ground water pollution. Unfortunately, the existing solid waste in the district is discarded in open dumping site which is not an appreciable scientific and engineering method of waste disposal. Since it causes breeding of flies, mosquitoes, rats, and other cockroaches, which are responsible for diffusion of different diseases to human. Also an open dump site of solid waste is a significant source of air pollution in surrounding area. Appropriate solid waste Management process eliminates hostile influences on the environment and human health and it will be a key factor for economic development and enhanced quality of life. Several processes are participated in adequately managing municipal solid waste. These comprise observing, collection, transport, processing, recycling and disposal (Parag S. et al, 2015).

In Rania district, households are the major contributors of municipal solid waste (MSW). This is because of the district is not adequately industrialized and is not much of a focus of commerce. As a consequence, the main sources of municipal solid waste are domestic activities.

Solid waste is a significant issue in more urban areas in Iraq and its Kurdistan Region. In Iraq, a massive amount of waste was generated after 2003 as a result of overpopulation, human activities and unlimited economic activities, which led to occur a serious of environmental pollutions (Jassim Mohammed Musheb, 2018). 
Recently, the today world has been challenged to a considerable increasing in waste disposal quantity into the environment arbitrarily. The high generation rate of solid waste has been well-known as one of the most critical environmental issues, and produces environmental consequences such as ground water and surface water contamination as a result of leachates; land contamination by direct solid waste discarded or leachate. In addition, air pollution when it burnt and lastly it is a major source of diffusion diseases by vectors such as insects, birds and rodents (Mohammad Tahir Mapa, 2011). Organic waste which is the most abundant portion of solid wastes, if poorly managed or disposed without treatment can result in degradation of water, soil and air qualities (Romeela Mohee, 2007).

The focused studying area of this research is Ranya district, which is a part of Sulaimanyah province located north east of the Sulaimanyah Governorate. The solid waste is one of the popular environmental issues in the district due to absence of proper solid waste management systems, recycling, source separation and nonscientific disposal method in the District.

There is a strong association between urbanization and environmental consideration, among these considerations, the crucial one is the quantity of solid waste which is generated at a rate that surpasses the ability of responsible organization such as municipality to manage it adequately. Also it will affect the urban environment, human health and the community life quality. Several other difficulties further complicated as a result of deficiency of budget and human resources skilled in solid waste management process which includes different steps such as sources generation, collection, separation, transportation and final discarding. In addition to that the waste reduction alternatives such as recycling, reusing \& recovery and reducing of the solid waste are obviously required and disorganized in most cases (Ruth F. et al, 2003) and (Jassim M. M. 2018).

The seasonal variation phenomenon on the earth surface is the result of annual gyration of the earth around the sun in combination with the angle of inclination with the earth generating variations in heat distribution. During summer (dry season) in the northern hemisphere, the weather is at its warmest because the sun is directly overhead at the Tropic of Cancer, while in winter (rainy season), in the northern hemisphere, it is colder because the sun is over the Tropic of Capricorn (Kirchhoff, da Silva, Browell, 1990).

Each location or residential area generates a different composition of solid waste since the sources generation is different depend on socio-economic factory, type of industry and level of industrialization , topographical location , weather, consumption rate, collection system, inhabitants concentration, the recycling alternative, authority controls and public awareness.

One of the most important causes that impact the magnitude of solid wastes generated is seasonal variation, as the volume of some kinds of solid waste are also affected by the season such as the food wastes are affected by the growing 
season for vegetables and fruits. The seasons can impact both the quantity certain kind of solid waste and the management process. (Suad M. G, 2012).

Majority of solid waste generated in the different cities of Iraq is disposed in open dumps, which it is unscientific, outmoded and ineffective approach for solid waste disposal (Tasnim F. Ch, 2016). The waste disposal process in the Ranya district is in open dumping site. Lack of developed recycling system, operational control and treatment of solid waste are the major sources of public health and different environmental issues (Chrakhan R.R, et al., 2018).

\section{SOLID WASTE STATUES AND TREATMENT:}

The study area is Ranya which is located in Sulaymaniyah Governorate, Iraqi Kurdistan Region, Iraq with Latitude and Longitude of 36.256248 and 44.882820 respectively. Furthermore, the district consists of four other sub-districts namely Haji-awa, Chwarqurna, Sarwchawa and.Betwata which are neighboring the Ranya city. The whole district area is $884 \mathrm{~km} 2$ (Kamara and Sarkar, 2018). The district population is about 228549 inhabitants at the center of district and sub districts, in addition, the total district population is about (258782) inhabitants (Raparin Statistics directorate, 2019).

The solid waste management process has been started since establishing of Ranya municipality in 1982, the generated waste in the Ranya city which is the center of the district had been collected and transported to Hajila hill at east of the city and dumped randomly without any treatment and covering process, which is burned partially at the site.. The process totally carried out by municipality, up to September, 2014. After that the responsibility of the solid waste management process has transmitted to private sector under the municipality supervising. The collection of solid waste performed regularly three times a week such as Curbside pickup and Community bin pick up methods (KRG, Ministry of Municipalities, 2019). Furthermore, the company is responsible to discard the waste in the disposal site which is an open area, without any treatment and other alternatives such as recycling, reuse and incineration Figure 1. United Nation Environment Programme (UNEP) supported a number of researches which dealing with magnitude and composition of urban solid waste and environmental valuation (UNEP- Iraq, 2007). 


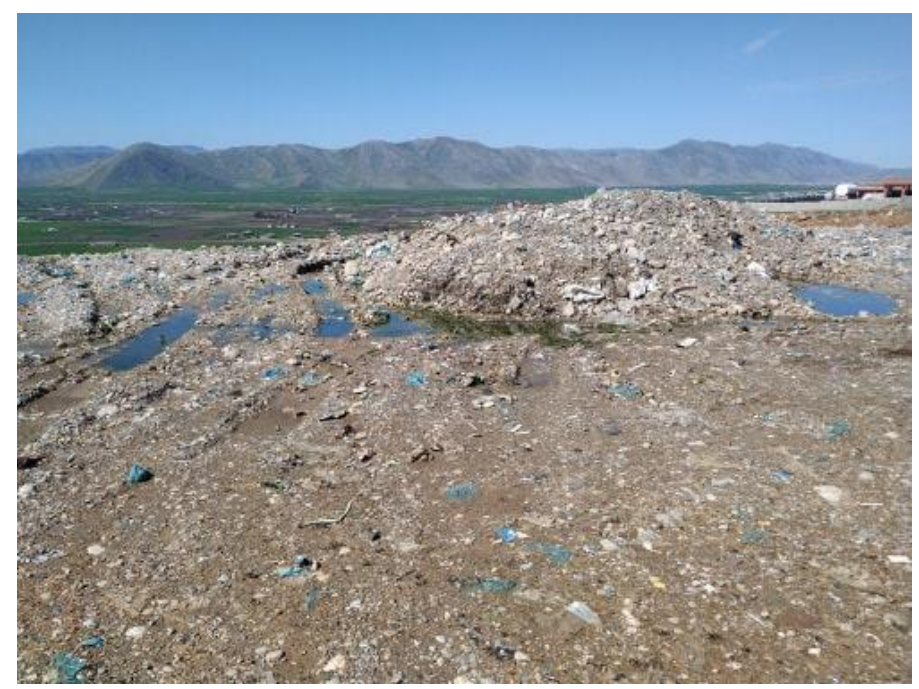

Fig. 1. Ranya waste disposal site.

Temporal and spatial variations of household waste in Ranya City have been investigated and the results revealed the average solid waste generated per capita was $0.850 \mathrm{~kg}$ and organic waste was the largest portion which is about $75 \%$ (Kamara and Sarkar, 2018). Another research has been done about characteristics and conformation of Solid waste of Mosul city (Sati M., et al., 2013). (Hatem K.B and Sajjda A.M, 2016) have conducted a research study about the impacts of construction projects waste on solid waste management process, the study results illustrate that the brick material forms the $13.5-16 \%$ of total solid waste in Iraq. Compositions of solid waste and seasonal variation effect on domestic waste have been studied in Tikrit city, Iraq, the research outcomes clarified that food waste percentage increase at the summer while paper and cardboard tended to increase at the winter (Waleed M. Sh. And Haneen A. K, 2013). Seasonal variation impacts on waste collection process in Ibadan, South-west Nigeria have been assessed in a research (Bolanle W. \& Bayonle O., 2018). In Romania (Gerardo C. et al, 2016) conducted a research study concerned the household waste characterization and seasonal variations in Bihor county, the results reveal that the largest portion of waste is organic matter which is $45.89 \%$, and the average of humidity increased from $47.89 \%$ to $58.27 \%$ from winter to summer season. While in Kurdistan Region of Iraq several researches about solid waste management have been done mainly in Erbil city, recyclable solid waste materials management has been studied in Erbil city (Shuokr et al, 2019). The assessment of environmental effect of Erbil dump site area has been studied and it found the negative impact on the around area (Sirwan Q.S Gardi, 2017). On the other hand, in the Sulaimanyah governorate which is a main part of Kurdistan region of Iraq, a research study has been conducted about solid waste management and (Dwbra valley open dump) in Chamchamal district focused as a case study (Chrakhan R. Rashid et al, 2018). The present study is an environmental study in the Sulaimanyah governorate which focuses on Ranya district. The main aim of this research study is to evaluate the seasonal variation impacts on the composition, characteristics and quantity of solid waste in the district. 


\section{MATERIALS AND METHODS:}

This study was conducted during winter and summer seasons during February to September 2019, since the solid waste generation, composition and its contents strongly affected due to seasonal variation and socioeconomic status (Gintaras D. et al, 2014). The data collection process has been done in both seasons, different samples randomly were collected and output data analysis was used by weighing the solid waste with truck scales.

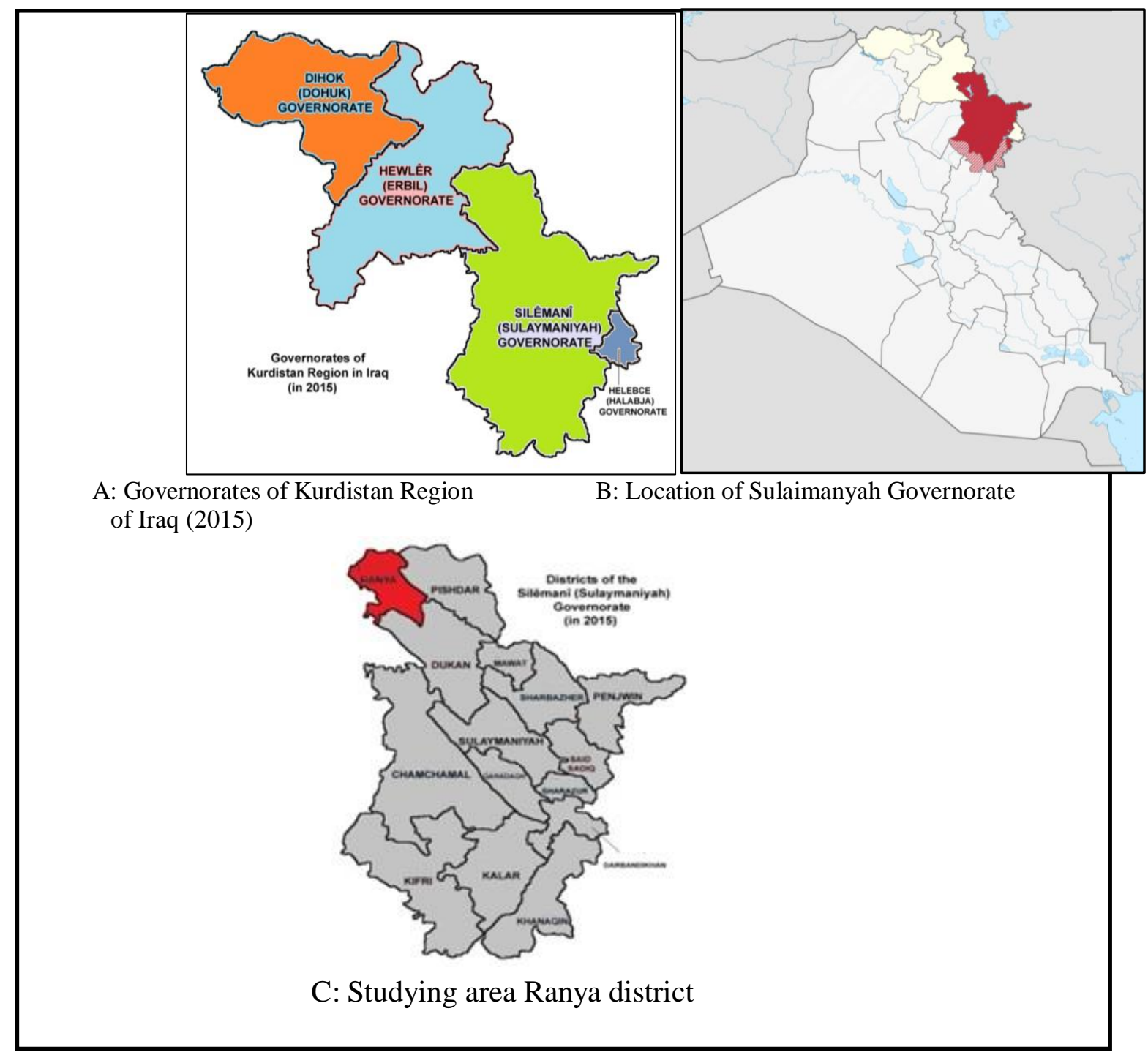

Fig. 2. The location of studying area

The studying area divided in to eight different zones in order to obtain an acceptable representative sample for the district solid waste, Zone 1 represents the center of Ranya city, Zone 2, Zone 3, Zone 4, Zone 5, Zone 6, Zone 7 and Zone 8 represent Haji-awa, Chwarqurna, Shkarta, Sarwchawa, Khdran, Bosken and Sarkapkan respectively Figure 2 and 3. In each zone the total generated solid waste was separately collected using compactor truck or dumper truck provided to absolutely convey the solid waste to dumping station, in selected days during the two periods and weighted 
by truck scale with cooperation of Privet Companies and municipalities to achieve the average of quantity of solid waste generated in each zones. Furthermore, to analyze the solid waste composition and identify the solid waste ingredients, the waste samples for each zone were mixed from different trucks which selected randomly and final sample was subdivided for four equal quarters, and the constituents were separated manually and weighed by using a digital balance and the percentage of each component was calculated Figure 4.

\section{RESULTS AND DISCUSSION:}

4.1 This section discusses the attained results of the research to analyze the main characteristics of studied solid wastes in the Ranya districts. The quantity, composition and generation rate of the solid waste are fluctuating from area to another area as well as in different periods of the year, since various aspects are influencing, such as life style, social and economic status, population concentration, industrialization, per capita income level and climate. (Sati M., et al., 2013). In order to determine the amount of waste generation rate in different seasons, the data collection and calculation process have been done for all collected samples from different zones, during both period. The total solid wastes generated in the district were evaluated as 268.37 tons and 305.44 tons for winter and summer seasons respectively. Also the average solid waste constituents and quantity for all zones in both seasons are shown in the Table 1 and Table

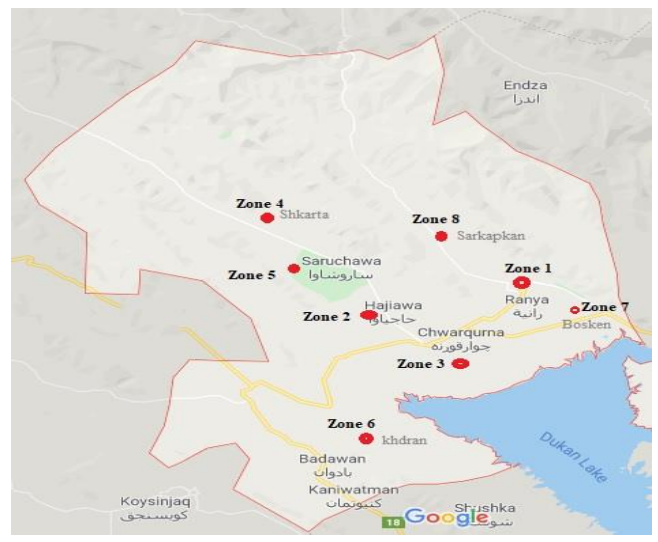

Fig. 3 Samples distribution in the studying area 

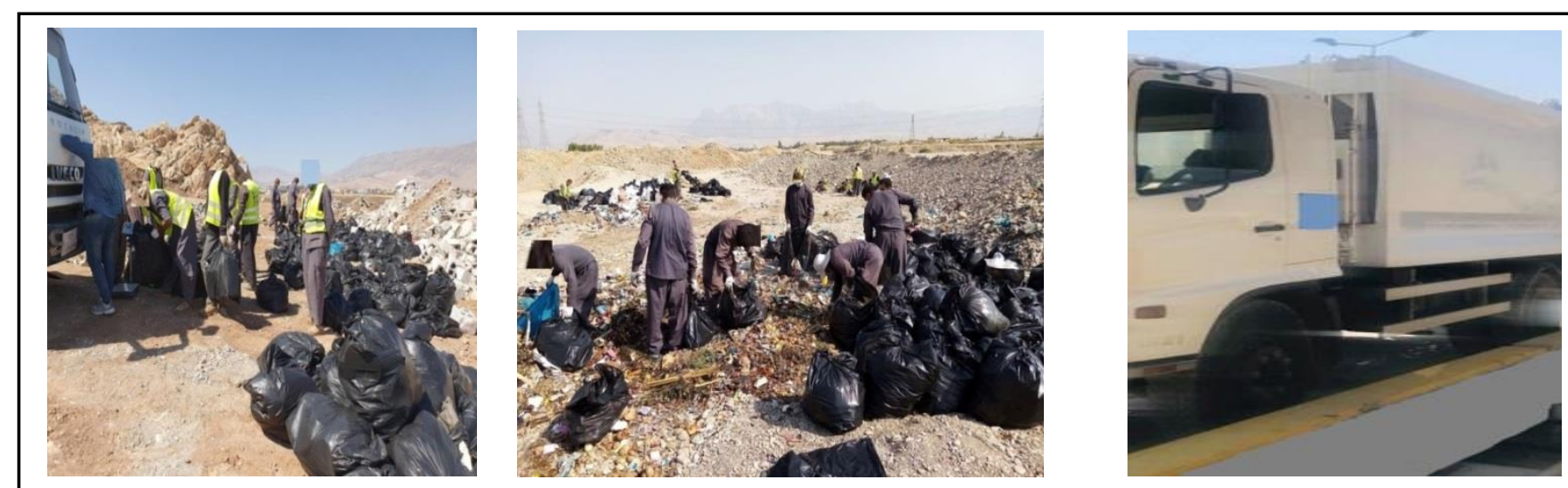

Fig. 4 Solid waste weighing and separation process

Table 1: Quantity and constittrents of solid wastes for wet season.

\begin{tabular}{|c|c|c|c|c|c|c|c|}
\hline \multirow[b]{2}{*}{$\begin{array}{c}\text { Studying area } \\
\text { Zones }\end{array}$} & \multirow{2}{*}{$\begin{array}{c}\text { Total solid } \\
\text { waste day } \\
\text { (Kg) }\end{array}$} & \multicolumn{6}{|c|}{ Main Components of the solid wastes } \\
\hline & & $\begin{array}{l}\text { Organic } \\
\text { matter } \\
\text { Kg/day }\end{array}$ & $\begin{array}{c}\text { Paper\& } \\
\text { Cardboard } \\
\text { Kg / day }\end{array}$ & $\begin{array}{l}\text { Plastic } \\
\text { Kg/ day }\end{array}$ & $\begin{array}{c}\text { Metal } \\
\text { Kg /day }\end{array}$ & $\begin{array}{l}\text { Glass } \\
\mathrm{Kg} / \text { day }\end{array}$ & $\begin{array}{c}\text { Cloth \& } \\
\text { Textile } \\
\text { Kg/day }\end{array}$ \\
\hline Zone 1 & 85900 & 27407 & 11704 & 13894 & 2672 & 3470 & 26753 \\
\hline Zone 2 & 69248 & 62593 & 2433 & 3138 & 417 & 278 & 389 \\
\hline Zone 3 & 50100 & 38950 & 2650 & 3000 & 1950 & 1500 & 2050 \\
\hline Zone 4 & 24500 & 22374 & 712 & 987 & 137 & 115 & 175 \\
\hline Zone 5 & 15940 & 14109 & 703 & 858 & 101 & 62 & 107 \\
\hline Zone 6 & 12140 & 8900 & 810 & 650 & 480 & 250 & 1050 \\
\hline Zone 7 & 8770 & 2795 & 1193 & 1417 & 282 & 354 & 2729 \\
\hline Zone 8 & 1772 & 378 & 112 & 298 & 165 & 234 & 585 \\
\hline $\begin{array}{l}\text { Total quantity } \\
\text { of solid waste }\end{array}$ & 268370 & 177506 & 20317 & 24242 & 6204 & 6263 & 33838 \\
\hline $\begin{array}{l}\text { Percentage\% } \\
\text { of solid waste }\end{array}$ & $100 \%$ & $66.14 \%$ & $7.57 \%$ & $9.03 \%$ & $2.31 \%$ & $2.33 \%$ & $12.61 \%$ \\
\hline
\end{tabular}

4.2 Solid Waste Components: The results reveal that the identified solid waste components can be categorized to six main categories of waste contents such as organic matter, paper and cardboards, plastic, metal, glasses and Cloth \& textile. From Table 3 and Figure 4 it can be observed that the organic matter is the most abundant component in the district's solid waste during both periods which the average rate is about $67.05 \%$, organic matter is decayed and biodegradable materials. And followed by cloth \& textile about $11.93 \%$, on the other hand, the least waste components are glass and metal which they are about $2.65 \%$ and $3.05 \%$ respectively. Although the average portion of paper \&cardboard and plastic waste ingredients are $7.12 \%$ and $8.19 \%$ respectively. The similar outcomes were achieved in other researches from Erbil, Baghdad and Turkey researches for instance in Istanbul these results were reported; organic matter $61.64 \%$, paper $5.72 \%$, plastic $8.75 \%$, metal $0.83 \%$ and glass portion was $4.6 \%$ (Huseyin K. O., et al., 2016) 
Table 2: Quantity and constituents of solid wastes for dry season, 2019

\begin{tabular}{|c|c|c|c|c|c|c|c|}
\hline \multirow[b]{2}{*}{$\begin{array}{l}\text { Studying area } \\
\text { Zones }\end{array}$} & \multirow{2}{*}{$\begin{array}{c}\text { Total } \\
\text { solid } \\
\text { waste } \\
\text { day }(\mathrm{Kg})\end{array}$} & \multicolumn{6}{|c|}{ Main Components of the solid wastes } \\
\hline & & $\begin{array}{c}\text { Organic } \\
\text { matter } \\
\mathrm{Kg} / \text { day }\end{array}$ & $\begin{array}{c}\text { Paper\& } \\
\text { Cardboard } \\
\text { Kg / day }\end{array}$ & $\begin{array}{l}\text { Plastic } \\
\mathrm{Kg} / \text { day }\end{array}$ & $\begin{array}{c}\text { Metal } \\
\mathrm{Kg} / \text { day }\end{array}$ & $\begin{array}{c}\text { Glass } \\
\mathrm{Kg} / \text { day }\end{array}$ & $\begin{array}{c}\text { Cloth \& } \\
\text { Textile } \\
\text { Kg/day }\end{array}$ \\
\hline Zone 1 & 91690 & 33513 & 10741 & 9240 & 7349 & 5120 & 25727 \\
\hline Zone 2 & 83435 & 75725 & 2325 & 3417 & 596 & 560 & 812 \\
\hline Zone 3 & 54300 & 42440 & 3010 & 3400 & 1840 & 1810 & 1800 \\
\hline Zone 4 & 27345 & 24098 & 810 & 1435 & 287 & 225 & 490 \\
\hline Zone 5 & 20185 & 16843 & 794 & 1695 & 296 & 165 & 392 \\
\hline Zone 6 & 14220 & 10845 & 850 & 860 & 395 & 290 & 980 \\
\hline Zone 7 & 8145 & 2690 & 1093 & 1311 & 342 & 311 & 2398 \\
\hline Zone 8 & 6120 & 1471 & 744 & 1087 & 506 & 592 & 1720 \\
\hline Total & 305440 & 207625 & 20367 & 22445 & 11611 & 9073 & 34319 \\
\hline Percentage\% & $100 \%$ & $67.96 \%$ & $6.67 \%$ & $7.35 \%$ & $3.80 \%$ & $2.97 \%$ & $11.24 \%$ \\
\hline
\end{tabular}

Furthermore, similar results were obtained in Mahabad town which organic matter formed 75\%, paper 3.79\%, plastic 9.78\%, metal 1.19\% and textile 1.9\% (Soran E., et al., 2015). Organic waste which is the major percentage the study, as well as it has characterized the largest quantity of potentially recyclable. Also there is a possibility of producing compost programmed for local nurseries, which is "a biological degradation or breakdown of organic substance under aerobic conditions (Hussein I. et al., 2018).

4.3 Municipal Solid Waste Generation rate: in order to calculate the solid waste generation rates in all zones of the district, all waste samples were collected and weighted during both periods. And amount of all generated wastes during wet and dry season and average of all generated wastes of the district estimated as 268.370 tons, 305.44 tones and 286.88 tones / per-capita/day respectively as demonstrated in Table 3. Moreover, based on district population and average of total quantity of generated waste, the average of solid waste generation rate per ( $\mathrm{kg} /$ capita-day) has been assessed as (1.108kg/ capita-day). The comparison of waste components and generation rates of the current study with 
the other local and international researches were displayed in Table 4, the waste generation rate in this study was $(1.037 \mathrm{~kg} /$ capita/day) for winter, $(1.180 \mathrm{~kg} /$ capita/day) for summer season and average waste generation is $(1.108 \mathrm{~kg} / \mathrm{capita} / \mathrm{day})$ reported, which is similar to the average waste generation rate reported for Europe and central Asia (1.18kg/cap-day) and in Cameroon.

Table 3: Average of solid waste quantity and contents of the Ranya district in wet and dry season.

\begin{tabular}{|c|c|c|c|c|c|c|}
\hline $\begin{array}{l}\text { Main Solid waste } \\
\text { contents }\end{array}$ & Wet $(\%)$ & Ton/Day & Dry $(\%)$ & Ton/Day & Average\% & Ton/Day \\
\hline Organic waste & 66.14 & 177.506 & 67.96 & 207.625 & 67.05 & 192.56 \\
\hline $\begin{array}{l}\text { Paper \$ } \\
\text { Cardboard }\end{array}$ & 7.57 & 20.317 & 6.67 & 20.367 & 7.12 & 20.34 \\
\hline Plastic & 9.03 & 24.242 & 7.35 & 22.445 & 8.19 & 46.69 \\
\hline Metal & 2.31 & 6.204 & 3.8 & 11.611 & 3.05 & 8.91 \\
\hline Glass & 2.33 & 6.263 & 2.97 & 9.073 & 2.65 & 7.67 \\
\hline Cloth \& Textile & 12.61 & 33.838 & 11.24 & 34.319 & 11.93 & 34.07 \\
\hline Total & 100 & 268.370 & 100 & 305.44 & 100 & 286.90 \\
\hline $\begin{array}{l}\text { Generation rate } \\
\text { (kg/capita-day) }\end{array}$ & \multicolumn{2}{|c|}{1.037} & \multicolumn{2}{|c|}{1.180} & \multicolumn{2}{|c|}{1.108} \\
\hline
\end{tabular}

Table 4: Comparison of solid waste generation rate, quantity and contents of the current study with other reported researches.

\begin{tabular}{|c|c|c|c|c|c|c|c|}
\hline $\begin{array}{l}\text { Other reported researches/ } \\
\text { References }\end{array}$ & $\begin{array}{l}\text { Generati } \\
\text { on } \\
\text { (kg/cap- } \\
\text { day) }\end{array}$ & $\begin{array}{l}\text { Organic } \\
\text { waste }\end{array}$ & $\begin{array}{c}\text { Paper } \$ \\
\text { Cardbo } \\
\text { ard }\end{array}$ & Plastic & Metal & Glass & $\begin{array}{l}\text { Cloth \& } \\
\text { Textile }\end{array}$ \\
\hline Current Study & 1.108 & 67.05 & 7.12 & 8.19 & 3.05 & 2.65 & 11.93 \\
\hline $\begin{array}{l}\text { Baghdad, Iraq (Tasnim } \\
\text { F.CH., 2016) }\end{array}$ & 0.900 & 70.00 & 5.00 & 5.30 & 2.20 & 2.20 & - \\
\hline $\begin{array}{l}\text { Mosul [18]Mosul, Iraq, } \\
\text { (Sati M.\&Taha A. ,2013) }\end{array}$ & 0.680 & 68.17 & 9.6 & 5.29 & 3.15 & 2.61 & 5.48 \\
\hline $\begin{array}{l}\text { Erbil, Iraq ( Yahya A. Sh., } \\
\text { 2011) }\end{array}$ & 0.420 & 76.0 & 5.00 & 5.00 & 3.00 & 4.00 & 2.00 \\
\hline $\begin{array}{l}\text { Erbil, Iraq ( Shoukr Q. et al. } \\
\text { 2019) }\end{array}$ & 1.27 & 28.00 & 13.00 & 35.00 & 2.00 & 2.00 & 5.00 \\
\hline $\begin{array}{l}\text { Babylon, Iraq ( Ali Chabuk, } \\
\text { et al., 2015) }\end{array}$ & 0.670 & 55.00 & 5.00 & 8.00 & 10.00 & 5.00 & 5.00 \\
\hline $\begin{array}{l}\text { Tehran, Iran ( Soran Erami, } \\
\text { et al., 2015) }\end{array}$ & 0.840 & 69.66 & 9.37 & 6.82 & 1.53 & - & 1.89 \\
\hline
\end{tabular}




\begin{tabular}{|c|c|c|c|c|c|c|c|}
\hline $\begin{array}{l}\text { GazaStrip, (Ahmad A. \& } \\
\text { Jehad H., 2012) }\end{array}$ & 0.660 & 52.00 & 11.00 & 13.00 & 3.00 & 3 & 18 \\
\hline $\begin{array}{l}\text { Cameroon, (Oben M. \& } \\
\text { Temateu Z.,2017) }\end{array}$ & 1.05 & 93.4 & 0.40 & 1.40 & 0.90 & 3 & 0.9 \\
\hline $\begin{array}{l}\text { Europe and Central Asia, } \\
\text { (Silpa Kaza, et al.,2018) }\end{array}$ & 1.18 & 36.00 & 18.60 & 11.50 & 3.00 & 8.00 & - \\
\hline $\begin{array}{l}\text { Average global waste } \\
\text { composition, (Silpa Kaza, et } \\
\text { al.,2018) }\end{array}$ & 0.800 & 44.00 & 17.00 & 12.00 & 4.00 & 5.00 & 8 \\
\hline
\end{tabular}

And it is higher than the average of global waste generation which reported as

(0.800 kg/capita-day) as well as the district waste generation rate is higher than some Iraqi cities such as Baghdad (0.900), Mosul (0.680) and Babylon (0.670). On the other hand, the evaluated generation rate is lower than Erbil city which is about $(1.27 \mathrm{~kg} / \mathrm{cap}$-day).

\subsection{Seasonal variation impacts on solid waste generation and composition percentage:}

the seasonal variation effects on solid waste generation and contents which observed in this research study demonstrate in the Table 5 and Figure 5. According to the attained date, the most considerable influences of seasonal variation effect can be observed in Metal and Glass content, the average quantity of metal in winter was 6.2 Tons/day, and it rose to 11.61Tons/day in dry season, the increment percentage is $87.13 \%$. Followed by glass content, which its quantity reported in wet season was 6.26Tons/day similar to metal content it grew up to 9.07Tons/day in dry season, and the increment rate is $44.81 \%$. The reason behind of high percentage of metal and glass in dry season is supposed to consumption of soft drinking metal cans and glass bottles such as Pepsi, Fanta, Sprite, Dew and Rani, etc...., which they are available in the Iraq and the district markets. The average quantity of total organic matter surged from 177.5Ton/day to 207.62Tones/day from winter to summer season. Since the most abundant organic matter composition is food and agriculture production, and both are subjected to damage due to high temperature during summer period which it rises to 45 to $47 \mathrm{C}^{\circ}$. On the other hand, the quantity of plastic reduced from 24.24Tons/day to 22.44tones/day from wet to dry season. Moreover, a slight change occurred in the paper, cloth and textile due to seasonal variation. Finally, the total generated solid waste magnitude of the district picked up from 268.37Tones/day to 305.44Tones/day with seasonal change from wet to dry. 


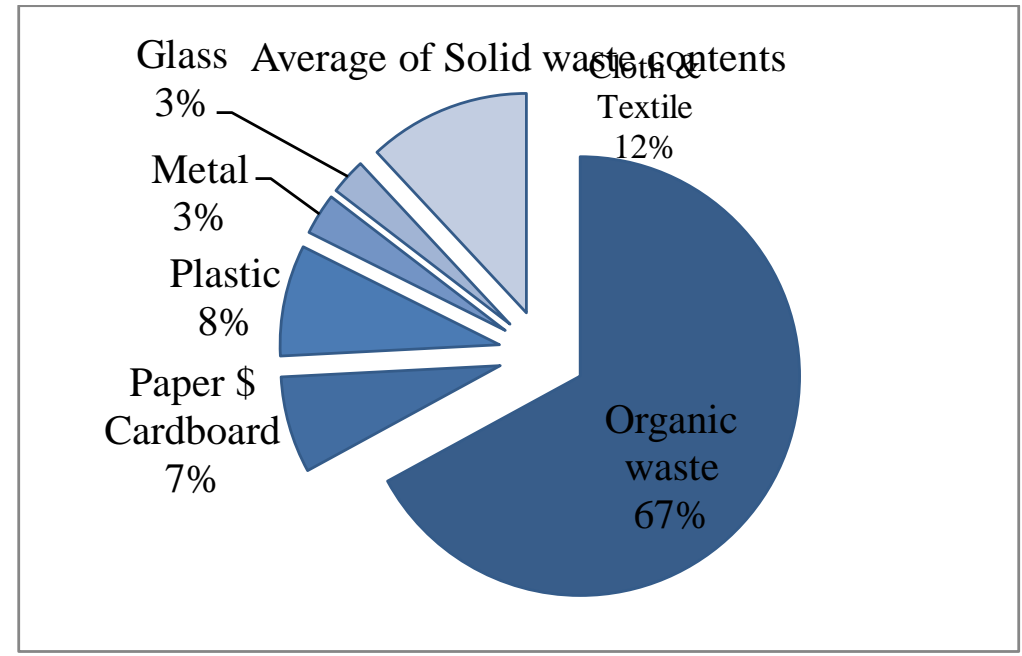

Figure 4. Average of Solid waste contents

Table 5: Seasonal variation impacts and Percentage Average of Solid Waste Contents.

\begin{tabular}{|c|c|c|c|c|}
\hline $\begin{array}{l}\text { Solid waste } \\
\text { Components }\end{array}$ & \multicolumn{4}{|c|}{ Solid Waste Contents (Tons) } \\
\hline Seasonal Effect & $\begin{array}{l}\text { Wet season } \\
\text { (Ton/day) }\end{array}$ & $\begin{array}{c}\text { Dry season } \\
\text { (Ton/day) }\end{array}$ & change $\%$ & $\begin{array}{c}\text { Average } \\
\text { (Ton/day) }\end{array}$ \\
\hline Organic Matter & 177.506 & 207.625 & +16.96 & 192.56 \\
\hline Paper & 20.317 & 20.367 & +0.24 & 20.33 \\
\hline Plastic & 24.242 & 22.445 & -7.42 & 23.34 \\
\hline Metal & 6.204 & 11.611 & +87.13 & 8.91 \\
\hline Glass & 6.263 & 9.073 & +44.81 & 7.66 \\
\hline Cloth \& Textile & 33.838 & 34.319 & +1.42 & 34.07 \\
\hline Total & 268.370 & 305.44 & +13.81 & 286.88 \\
\hline $\begin{array}{l}\text { Generation rate } \\
\text { (kg/capita-day) }\end{array}$ & 1.037 & 1.180 & & \\
\hline
\end{tabular}




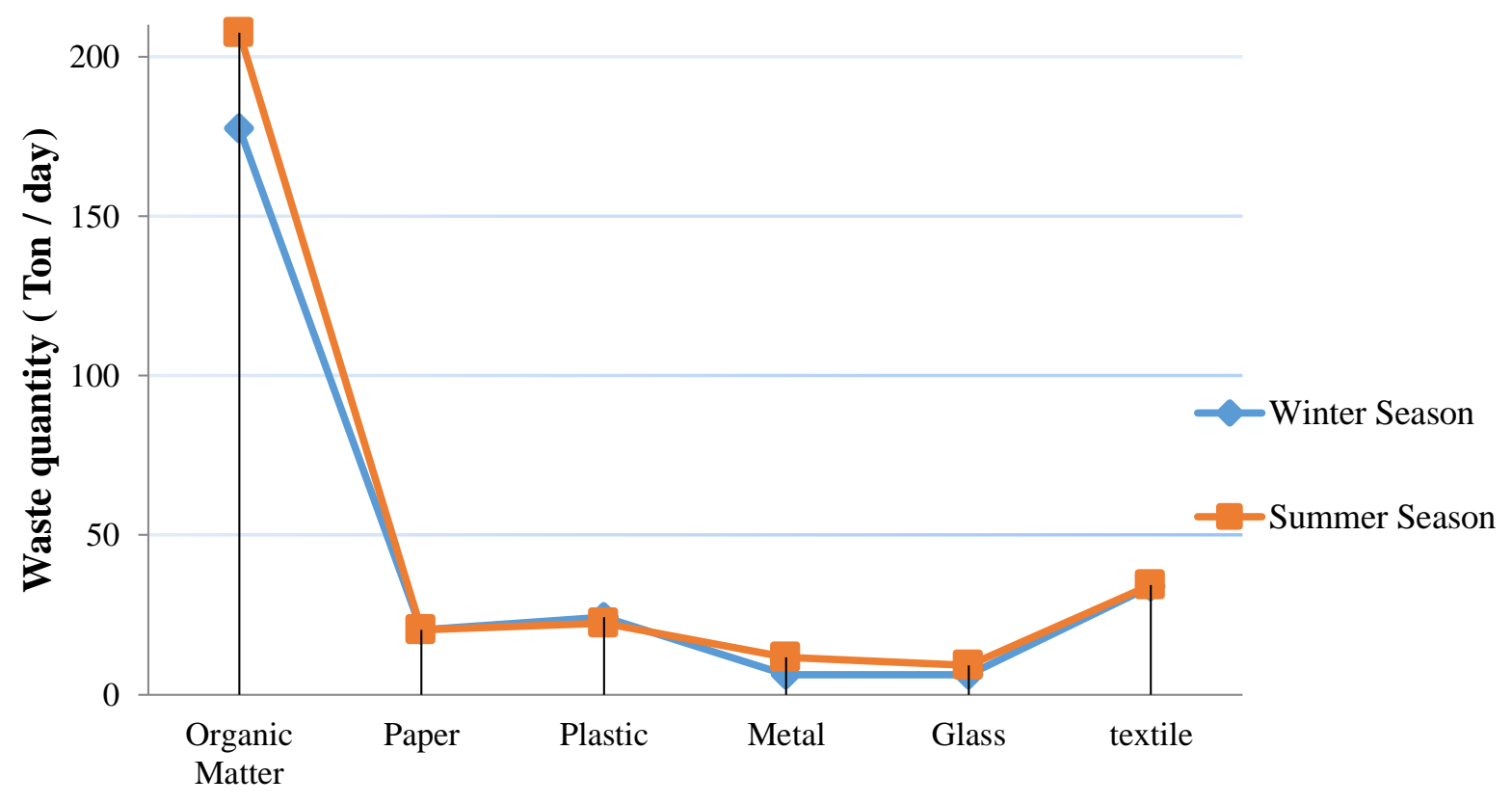

Solid waste Components

Figure 5: Seasonal variation influences on solid waste contents.

\section{CONCLUSIONS:}

Recently, the solid waste generation has become a significant issue in the urban area due to urbanization, population, industrialization and economic development. The current study focused on seasonal variation influences on solid waste generation, and solid waste components of Ranya district in Sulaimanyah governorate, Kurdistan region of Iraq. The results of the study illustrate the significant impacts of seasonal variation on solid waste generation and some ingredients. It has been found that the total amount of generated waste in the district is 268.37Tones/day, 305.44 tons/day in wet and dry season respectively. And the average of solid waste magnitude is 286.9Tones/day. Moreover, the average waste generation rate has been evaluated as $1.108 \mathrm{~kg} /$ capita-day, which is similar to the average waste generation rate reported for Europe and central Asia (1.18kg/cap-day) and in Cameroon (Daniel et al, 2012). And it is higher than the average of global waste generation which reported as $(0.800 \mathrm{~kg} / \mathrm{capita}$-day) as well as it is higher than some Iraqi cities such as Baghdad (0.900), Mosul (0.680) and Babylon (0.670) (TasnimF.CH., 2016, Sati M.\&Taha A. ,2013, and Ali Chabuk,et al., 2015 ) . On the other hand, the evaluated generation rate is lower than Erbil cities which about (1.27 kg/cap-day) (Shoukr Q. et al. 2019). The results discovered that the Organic waste is the most abundant ingredients of the solid waste in both period's winter and summer which is about $66.14 \%$ and $67.96 \%$ respectively. On the other hand, the least waste components are glass and metal which they are about $2.65 \%$ and $3.05 \%$ respectively.

\section{ACKNOWLEDGEMENTS:}


We would like to thanks Raparin Municipalities Directorate and Garex Company for valuable cooperation in data processing and providing us fundamental information on fulfillment of this research.

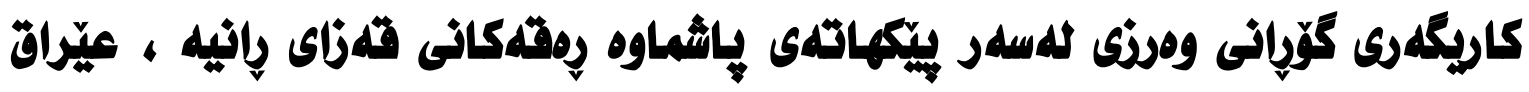

نَاراز احمد همزه

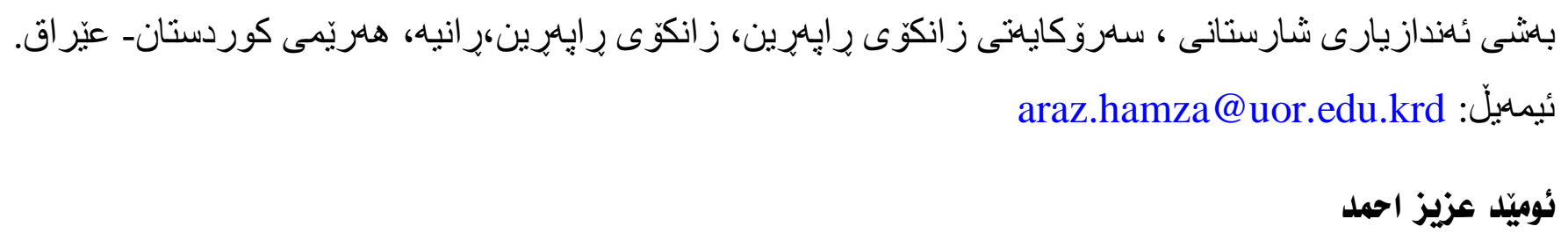

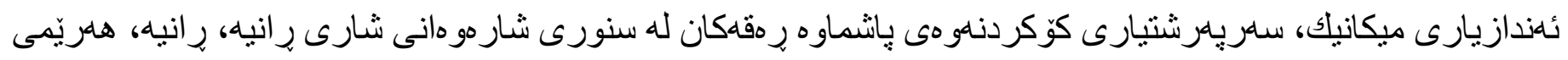

$$
\text { كوردستان- عبّراق. }
$$




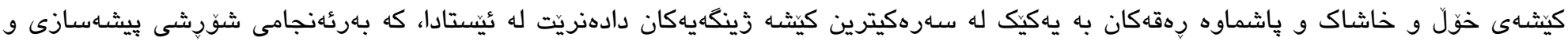

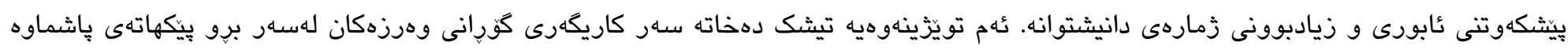

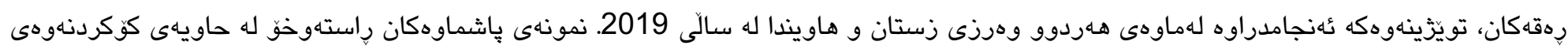

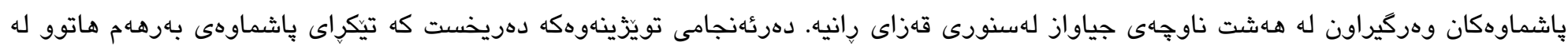

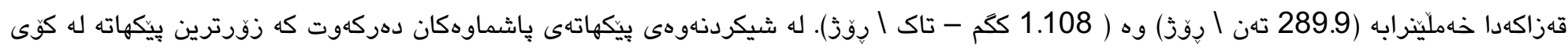
باشماوهى شارهكه بريتى يه له ماددهى ئهدامى كه تيكراى ريّزّكهى دهكاته 67.05\%. بهدواى دا ريّزّهى جل و بهرك و بِاستيك و كاغهزو كارتقن و

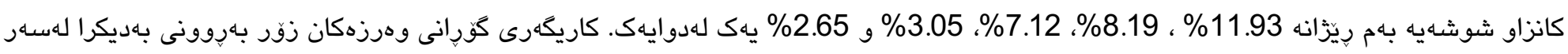

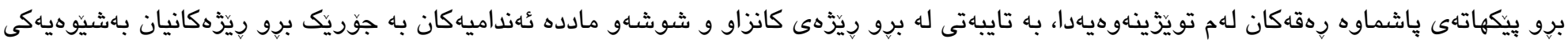

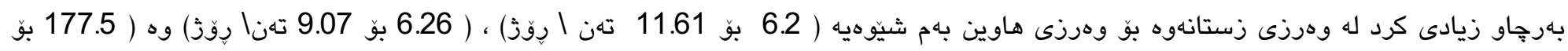
207.62 تهن إقوذ) يهك له دواى يهك. له هـمانكاتدا كوى كثتى برى باشماوهى بهرههم هاتوو له قهزاكها زيادى كردووه له 268.37 تهنابرقذ له وهرزى زستاندا بو 305.44 تهن إِوَّ له وهرزى هاويندا.

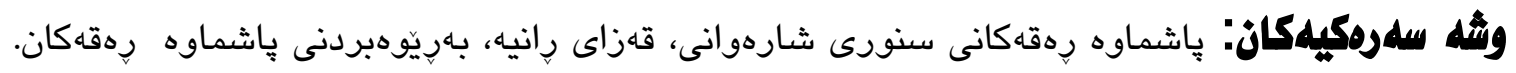

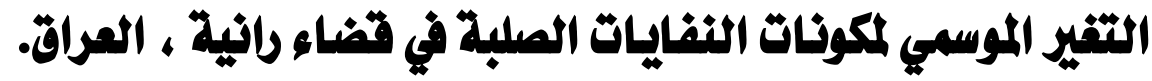

قسم الهندسة المدنية ، رئاسة جامعة رابهرين ، جامعة رابهرين ، رانيه، اقليم كردستان- العراق.

أراز احمد همزه araz.hamza@uor.edu.krd : البريد الإكتروني

مهندس ميكانيكي ، مشرف على المخلفات الصلبة الإدارة في رانيه ، بلدية رانيه، رانيه، اقليم كردستان- العراق. نوميد مزيز احمد Omed_hemn@yahoo.com : البريد الإكتروني 
يمكن اعتبار النفايات الصلبة البلدية احدى من القضايا البيئية الهامة في جميع أنحاء العالم ، نتيجة للثورة الصناعية والتنمية الاقتصادية والاكتظاظ السكاني. ركزت الدراسة الحالية على التنوع الموسمي لإنتاج وتكوين النفايات الصلبة. أجريت الدراسة خلال فصل الشتاء والصيف في عام 2019. تم جمع عينات من النفايات الصلبة من حاويات التجميع من ثماني مناطق مختلفة في منطقة رانية. أوضحت النتائج بأن متوسط إجمالي توليد النفايات الصلبة في المنطقة يقدر بـ (286.9 طن / يوم) و (108 كجم / فرد / يوم). كشف تحليل محتوى النفايات أن الجزء الأكبر من النفايات الصلبة للمنطقة هو المواد العضوية التي تشكل في المتوسط 67.05٪. يليها القماش والمنسوجات والبلاستيك والورق والكرتون والمعادن والزجاج بكمياتها 93.93\% و 8.19٪ و 7.12\% و 2.05\% 2.65\% على التوالي. تم الحفاظ على تأثيرات التباين الموسمي على النفايات الصلبة بوضوح في هذه الدراسة البحثية ، وبشكل أكثر تحديدًا في محتويات النفايات المعدنية والزجاجية والعضوية ، والتي زادت كمياتها بشكل كبير من الموسم الرطب إلى الجاف ، (6.2 إلى 11.61 طن / يوم) ، (6.26 إلى 9.07 طن / يوم) و (177.5 إلى 207.62 طن / يوم) على التوالي. علاوة على ذلك ، تخير إجمالي حجم النفايات الصلبة المتولدة للمنطقة التي تم جمعها من 268.37 طن / يوم للموسم الرطب إلى 305.44 طن / يوم لموسى الجفاف. الكالمات اللدائحج النفايات الصلبة البلدية ، منطقة رانية ، إدارة النفايات الصلبة.

\section{References:}

Ali Chabuk,Nadhir Al.A, Hussain M. H., Sven K. and Roland P., [2015] "Present status of solid waste management at Babylon governarate, Iraq", scientific research publishing, Engineering, 2015, 7,408-423.

Ahmed Abdalqader and Jehad Hamad, [2012], "Municipal Solid Waste Composition Determination Supporting the Integrated Solid Waste Management in Gaza Strip", International Journal of Environmental Science and Development, Vol. 3, No. 2, April 2012.

Bolanle Wahab and Bayonle Ola, [2018], "Effects of Seasonal Variation on Informal Waste Collection in Ibadan, South-west Nigeria”, Environment and Pollution, Vol. 7, No. 1; 2018, ISSN 1927-0909 E-ISSN 1927-0917. 
Chrakhan R. R., et al. [2018], "Solid waste management: case study in Chamchamal (Dwbra valley open dump), Sulaimani, Kurdistan Region”, Geoscience Session, ICNS Proceding:PISSN: 2616-5457. e- ISSN: 2520-5749.

Daniel Hoornweg and Perina. Bhada-Tata, [2012], “What a Waste: A global review of solid waste management”, Urban Development series, World Bank, World Bank, 1818 H Street NW, Washington, DC20433, U.S.A.

Daniel Hoornweg and Laura Thomas, [1999], “What a Waste: Solid Waste Management in Asia”, Urban development sector unit East Asia and Pacific Region, The International Bank for Reconstruction and Development/ the World Bank, 1818 H Street NW, Washington, DC20433, U.S.A.

Gerardo Collaguazo, Adrian Badea, Constantin Stan and Zoltan Pasztat, [2016], "Household Wastes Characterization and Seasonal Variations in Bihor County, Romania”, U.P.B. Sci. Bull., Series C, Vol. 78, Iss. 1, 2016, ISSN 22863540.

Gintaras Denafas, Tomas R., Dainius M., Sergey Sh. H., Valeriy M., Stanislav O., Mikhail R.,Ekaterina N, Alexander Ch., Tsitsino T., Inga B.,Christian L.,[2014], "Seasonal variation of municipal solid waste generation and composition in four East European cities", Resources, Conservation and Recycling 89 (2014) 22-30, ELSEVIER.

Huseyin Kurtulus O., Senem Y.G., Lokman G. and Goksel D., [2016], "Municipal solid waste characterization according to different income levels: a case study", Sustainability 2016, 8, 1044; doi: 10.3390/su101044. Hussein I. Abdel-Shafy and Mona S.M., [2018], "Solid waste issue: Sources, composition, disposal, recycling, and valorization", Egyptian Journal of Petroleum 27(2018) 1275-1290, Elsevier.

Hatem K.B. Alajeeli and Sajjad A. M. Al Kaabi, [2016], “ A Study of Waste Management Reality in Construction Projects in Iraq", Wasit Journal of Engineering Science Vol. (4), No. (1), 2016.

Hussein I. Abdel-Shafy and Mona S.M., [2018], "Solid waste issue: Sources, composition, disposal, recycling, and valorization", Egyptian Journal of Petroleum 27(2018) 1275-1290, Elsevier. 
Jassim Mohammed Musheb, [2018], “The Economics Of Waste Recycling In Iraq: Wasted Resources And Lost Opportunities", European Journal Of Economics And Business Studies, Vol 4 No 2, ISSN 2411-9571(Print), ISSN 2411-4073 (Online).

Kamaran Tahir S. and Sarkar Hamad Kh., [2018], "Geographical Analysis of Spatial and Temporal variation of Solid Waste in Ranya City", Journal of University of Raparin, E-ISSN: 2522 - 7130 P-ISSN: 2410 - 1036.

Kurdistan Region Statistics office, Ministry of planning, Kurdistan Regional Government. Raparin Statistics directorate, Ranya, 2019.

Kurdistan Regional Government, Ministry of municipalities and Tourism, Raparin municipality directorate, planning and environment department (2019).

Mohammad Tahir Mapa,[2011], “ waste management and society: a case study of public participation in waste management Kota Kinabalu City", Health and the environment Journal, 2011, Vol. 2, No. 2.

Oben Mbeng L. and Tematen Zemtsa P, [2017], "Waste Characterization in the Bafoussam II Municipality of Cameroon", International Journal of Science and Research (IJSR) ISSN (Online): 2319-7064 Index Copernicus Value (2016): 79.57 | Impact Factor (2017): 7.296.

Parag S. Dawane and Prof.Sagar M. Gawande, [2015], "Review article Solid waste management- a review”, International Journal for current research Vol. 7, Issue, 05,pp-16019-16024,May,2015.

Ruth F. Weiner and Robin Matthews, [2003], “Environmental engineering”, Fourth Edition, Copyright @2003, Elsevier Science (USA). All rights reserved. 
Romeela Mohee, [2007], “waste management opportunities for rural communities, composting as an effective waste management strategy for farm households and other", Agricultural and food engineering working document, food and agriculture organization of the united nations Rome, 2007.

AZIZ,S. Q., ISMAIL,S.O.\&OMAR,I.A. , "Recycling Solid Waste Materials Management in Erbil City- Iraq. 2019 International Journal of Engineering Inventions, e-ISSN: 2278-7461, p-ISSN: 2319-6491, Volume 8, Issue 1, PP: $57-62$.

Sirwa Qader S.G., [2017], "Environmental impact assessment of Erbil dumpsite area - west of Erbil city-Iraqi Kurdistan Region", Journal of Tethys, Vol. 5, No. 3, 194-217.

Soran Erami, Behzad Sh. And Afshin Maleki., [2015], "Municipal solid waste management in Mahabad town, Iran”, Journal of Environmental science and technology, 2015, ISSN 1994-7887/DOI: 10.3923/jest.2015.

S.O. Adefemi and E.E. Awokumni, [2009], “ The impact of municipal solid waste disposal in Ado-Ekiti metropolis, Ekiti-State, Nigeria", African Journal of Environmental science and Technology Vol. 3(8), pp. 186-189, August, 2009, ISSN 1991-637X@2009 Academic Journals.

Sati M. Al-Rawi and Taha A. Al- Tayyar,[2013], “ A study on solid waste composting and characteristics of Mosul city / Iraq”, Journal of university of Zakho, Vol. 1. (A) No.2, Pp 496- 507, 2013.

Suad Mahdi Gleawa, [2012], "Seasonal Variation in Hilla municipal solid aste composition”, Journal of University of Bable, Engineering Science Vol. 20, No 1, 2012.

Silpa Kaza, Lisa Y., Perinaz B. and Frank V.W., [2018], “ what a waste 2.0, A global Snapshot of Solid waste Management to 2050", international Bank for Reconstruction and Development/ the World Bank, 1818 H Street NW, Washington, DC20433. 
Tasnim F. CH., [2016], " Solid waste generation and rate components percentage in Baghdad city", Journal of Engineering and Sustainable development, Vol. 20, No. 06, November 2016, ISSN 2520-0917.

UNEP in Iraq, [2007], "Post-conflict assessment, clean-up and reconstruction”, ISBN:978 92- 807-2906-1, Job No. DEP/1035/GE.

Kirchhoff, I. M. O. Da Silva and E. V. Browell, [1990], “Ozone Measurements in Amazonia: Dry Season versus Wet Season”, Journal of Geophysical Research, Vol. 95, No. D10, Pages 16,913-16,926, September 20, 1990.

Waleed M. Sh. Alabdraba and Haneen A. K. Al- Qaraghully, [2013], "Composition of Domestic Solid Waste and The Determination of its Density \& Moisture Content: A case study for Tikrit city, Iraq”, International Review of civil Engineering (I. RE. C. E.) Vol. 4, N.2, 2013.

Yahya Ahmed Shekha, [2011], "Household solid waste content in Erbil city, Iraqi Kurdistan Region, Iraq" Zanko J. Vol. 23 NO.3. 